\title{
Transatlantica
}

Revue d'études américaines. American Studies Journal

The Right Tone for the Hardest Moments: Louisa May Alcott's New York Stories of Child Labor and Urban Benevolence in the Mid-1870s

\section{Daniela Daniele}

\section{(2) OpenEdition}

\section{Journals}

Electronic version

URL: https://journals.openedition.org/transatlantica/14642

DOI: $10.4000 /$ transatlantica. 14642

ISSN: 1765-2766

Publisher

Association française d'Etudes Américaines (AFEA)

Electronic reference

Daniela Daniele, "The Right Tone for the Hardest Moments: Louisa May Alcott's New York Stories of Child Labor and Urban Benevolence in the Mid-1870s", Transatlantica [Online], 2 | 2019, Online since 01 October 2020, connection on 01 February 2023. URL: http://journals.openedition.org/transatlantica/ 14642 ; DOI: https://doi.org/10.4000/transatlantica. 14642

This text was automatically generated on 1 February 2023

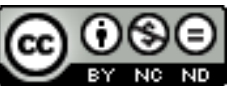

Creative Commons - Attribution-NonCommercial-NoDerivatives 4.0 International - CC BY-NC-ND 4.0 https://creativecommons.org/licenses/by-nc-nd/4.0/ 


\title{
The Right Tone for the Hardest Moments: Louisa May Alcott's New York Stories of Child Labor and Urban Benevolence in the Mid-1870s
}

\author{
Daniela Daniele
}

\section{Introduction: More Letters from New York}

Unlike civilized Boston, in Victorian America New York was unanimously criticized for the poor's dehumanizing condition. Before Lydia Maria Child's acclaimed Letters from New York (1843), the need for far-reaching urban social reform had already been tackled by another prominent woman traveler, Margaret Fuller. In 1844, the Dial's first female editor published up to 250 reports on slavery, the Sing Sing prison, the mistreatment of Irish immigrants, and prostitution in the city slums, concluding that the philanthropic policies enacted by the half-way houses for the poor and the abused only deepened their conditions of dependence. Later on, Rebecca Harding Davis's proletarian fiction inspired Louisa May Alcott's 1875 own account of the big city's myriad social ills, such as heavy drinking, child labor, or the terrible living conditions which hit harder on the little ones. Unlike her mother, the social worker Abigail May, Alcott was never an active philanthropist, opting instead to express her political concerns through her works of fiction, though without a hint of jugdment or excessive moralism. Still, hers was a firm, reforming spirit-one that compelled her to lend unwavering support to the fight for more equal relations between the races and the sexes, as her frequent contributions to the Woman's Journal testify. The author's mid-1870s tour of New York and the benevolent tales that she based on that trip are the focus of this article. Its aim is to convey the unrelenting humanist spirit inherited from her transcendentalist parents, as well as her controversial fascination with the new mercenary and entrepreneurial 
strategies lurking behind postbellum philanthropic institutions for the homeless. From its start, Alcott's benevolent journey into the metropolis was nothing like the ordinary Christmastime charity rounds paid by many a genteel lady to benevolent institutions. In her New York tour, she extensively covered orphanages, asylums, the dreadful Tombs prison, newsboys' shelters, idiot houses, and hospitals for the blind. And much of her mid-1870s literary production originates from her exposure to almshouses for young street vendors or to the traumatic urban realities of prostitution and adult prisons (earlier recounted in her 1873 novel, Work: A Story of Experience). The stories of those unfortunates are vividly documented and, in many respects, euphemized and fantasized by the writer, according to the successful domestic formula introduced in the Little Women saga (1868-1886), which glossed over the more gruesome aspects of the protagonists' genteel poverty to make them suitable for young readers.

2 As evident in the bittersweet tone of her fictions for adolescents, Alcott could turn even the worst cases of juvenile distress into pleasant learning occasions, drawing her inspiration directly from her parents-that is, more specifically, from the liberal pedagogy of her father Bronson and the altruism of her mother Abigail May who, in the 1840s, had run a placement office in Boston's High Street for Irish women immigrants. It was during her mother's illness that Alcott planned her 1875-1876 New York stay. Abigail May's philanthropic missions in Boston were an important source for her daughter's benevolent tales of child poverty, which Alcott initially conceived as a chapter in a longer edifying portrait of her mother, starting with her painstaking attempts to save many a woman worker from prostitution. Quite interestingly, that urban quest finally resulted in Alcott's own personal journey to temperance and recovery from opium addiction, which she had developed during the Civil War, when, as an army nurse, she had used laudanum to counter the toxic effect of calomel-a purgative against the typhoid fever which almost killed her in a Washington camp hospital.

3 Given her poor health, her family had greatly encouraged that New York journey, reasoning that a change of scenery would lift her spirits and prove healing in the end. Based on the author's letters home with little change from her original correspondence, Alcott's stories of temperance and benevolence were later collected in Silver Pitchers (1876) as non-saccharine and humorous sketches intended for young adults. ${ }^{1}$ In their outward didactic purposes, those tales were also meant as a tribute to her father's lifetime devotion to children's education-an homage equally evidenced by the book's dedication to her adolescent nephews and to those urban philantropists who, like her father, devoted their lives to stray children and juvenile delinquents.

\section{Juvenile Charms and Social Realism}

4 As most biographers have argued, Alcott's lifelong concern was to provide for her family by taking upon herself responsibilities that her parents had long neglected as a result of their full absorption in their Christian crusades. And while she never officially joined them in their philanthropic rounds, her own New York charity visits were still largely informed by the contacts that they provided. Under their friends' guidance, she found the city's new benevolent public institutions comparatively more efficient, far removed from the domestic scale of the boarding-house where her mother sheltered many stray children or women in search of employment (Alcott Journals of 1852, in 
Myerson and Shealy, 1989 67). Her family's charity rounds in Concord were likewise expended on a voluntary, even informal basis, calling on a form of Christian empathy which often stigmatized her parents as utopian dreamers within their Puritan community.

When she met the Romantic educator Bronson Alcott along with the other Concord sages in 1862, Rebecca Harding Davis was quick to notice his marginal and disadvantaged position. As Tillie Olsen acutely reports, Davis had a distinctive perception of the Alcotts as "'radicals, believers in divorce and women's rights, refusing to eat sugar or use cotton, visited once by John Brown,' who (naturally) were 'social outcasts'" (Olsen 77). While their precarious finances had not prevented their daughter from receiving an exceptionally advanced and liberal education at the hands of their transcendentalist neighbors Emerson, Hawthorne, and Thoreau, still their home nonetheless gave Davis a desolate impression of poverty and loneliness. As for Louisa, she had so much wanted to meet her established colleague that she walked all the way home to Concord for her one decent dress. "I'm very poor," she told Rebecca, who reported that "she had once taken place as a 'second girl." Reflecting on the same encounter, Louisa observed in her May 1862 journal how distant she felt from the proletarian style of the "author of Margret Howth, which had made a stir," depicting her as a "handsome, fresh, quiet woman, who says she never had any troubles, though she writes about woes. I told her I had had lots of troubles, so I write jolly tales; and we wondered why we each did so" (Myerson and Shealy, 1989 109).

That brief but significant episode helps position Alcott's benevolent realism by contrast with Davis's early naturalism, which, in her view, left her (mostly adult) readers little room for hope. Alcott sincerely appreciated her colleague's skilful use of Black and Irish vernaculars and did not hesitate to incorporate them in her own fiction, as other pioneers (such as E.D.E.N. Southworth, Lydia Maria Child, Harriet Spofford, and Metta Victoria Fuller Victor) had before her. However, when faced with New York's many social ills, she instinctively rejected Davis's stark naturalism, opting for a bittersweet tone instead-one that testified to first-hand knowledge of the margins, yet strove to sweeten those grim realities for her young readers.

7 Though "various kinds of convergence [...] inform[ed] the interrelation of philanthropy and realism" (Christianson 1), Alcott willfully mitigated Davis's documentary approach to urban poverty with a self-professed "jolliness" which made even the darkest scenes of destitution less distressing for her young audience. Hence, Davis's naturalistic accents never transpire in Alcott's starkest accounts of urban decay and child exploitation. As an experienced writer for adolescents, she was convinced that even in the most trying situations (as sensationally reported in popular magazines like Harper's), children did not merely require bread and butter but the joyous charms of entertainment. As a consequence, whenever her tales took a Dickensian, tragicomic turn, ${ }^{2}$ they never lacked the warm spirit of sympathy and compassion which charities sought to stir up during the ritual Christmastime visits to the orphans' and newsboys' shelters.

8 Those disciplining shelters legitimized child labor, conforming it to the demands of the marketplace. In their embrace of shelters as legitimate workplaces, Alcott's New York tales testify to utilitarian efforts to turn orphans and delinquents into productive agents of postbellum America's social progress and economic growth. Much in contradiction with her parents' disinterested reformism, Alcott's destitute children 
inadvertently became active vehicles for the entrepreneurial public policies endorsed by the new charity institutions, in conformity with the 1870s' aggressive system of production, capitalization, and investment. ${ }^{3}$ Somewhat reflecting Victorian literature's double address to both adult and young readers (Sánchez-Eppler xxIII), the orphans portrayed by Alcott awkwardly mimic an adult world whose concern for social promotion jars with their youthful innocence. In Silver Pitchers, Alcott's didactic ambitions to shape good citizens are likewise countered by the tales' prohibitionist ethos of surveillance and containment of the poor. Reflecting the efforts of new public charities to train vagrant children in the arts of sales and savings, her young workers thus seem to emulate the success story of Horatio Alger's Ragged Dick-the rags-toriches story of a shrewd foundling, published in 1868.

Behind the sentimental trappings of a simple novel for adolescents, Little Women (also published in 1868) presents the professional growth of four girls as impoverished and industrious as Alger's hero. However, in the New York tales, the March sisters' dignified poverty and New England family idyll was replaced by a bleaker depiction of equally industrious orphans involved in the intensive production, marketing, and investing programs enacted by the new generation of managerial philanthropists. Alcott thus applied the Protestant work ethic that had previously informed her "little women" directly to the city's orphans and street vendors, according to a rehabilitation program which instantly turned them into miniaturized economic agents eager to rise above their station, for ever dispossessed of their right to grow and play. Written during the capitalist expansion of the Reconstruction era, their stories reflect the Victorian marketplace's complete lack of protective legislation on the exploitation of minors, long before the first National Child Labor Committee was formed in 1904. In contrast with the transcendentalist and democratic sensibility of Alcott's parents, this era of business growth extended its profit-making machinery to social service. No less important in situating her New York tales are the deep financial crises which, time and again, brought Louisa May Alcott back to the grim memories of her long literary apprenticeship when, much like Christie in the 1873 novel Work, she trod many a muddy Boston street vainly looking for a job.

The disenchanted daughter of a social worker and a utopian reformer (whose inspirations drew from Robert Owen's protosocialist experiments and Rousseau's liberal pedagogy), as a girl Louisa had worked as a seamstress, teacher, and domestic servant to support her family. She failed to pick up on their philanthropic inclinations, as her survival instincts eventually prevailed over her family's unending compassion for the disenfranchised. Louisa was quick to establish herself as a skilled and shrewd manager of her unexpected literary fame and, in a pragmatic calculation, readily traded her authentic talent for sensation for the prolific output and mass circulation expected of a popular writer. By no coincidence, Alcott's New York children display an identical-if not premature-eagerness to make good use of their small profits. Such biographical echoes make Silver Pitchers, though a mere potboiler in Alcott's eyes, an especially compelling tale of young vagabonds determined to reverse their tragic fate. ${ }^{4}$

Those stories drew not just from her parents' philanthropic endeavors, but from dramatic engravings of New York poverty originally published in Harper's magazine and since recovered by John Grafton in 1977. Focusing on urban vagrancy, these engravings provide striking parallels with Alcott's own accounts of the detention and exploitation of abandoned children at the hands of public authorities, demonstrating her knack for 
capturing her contemporaries' taste for urban sensations and even inspiring artists and illustrators, as I will show.

While Alcott's war tales (especially her picaresque Hospital Sketches of 1863) owed much to her uncomprimising abolitionism and to Dickens's comic tragedies, her mid-1870s tales addressed-in the sensational style typical of such illustrated papers-the largely unexplored themes of city charities, which Abigail Gibson and some of her parents' reformer friends had encouraged her to visit. Once personally faced with New York's destitutes, Alcott instinctively resisted the condescending attitudes of genteel ladies, whose efforts to alleviate urban poverty often resulted in a morally gratifying form of self-empowerment (Womack 113). In her observation of the largely untrodden scene of urban philanthropy, Alcott likewise rejected the inspective rhetoric of social purification and temperance of Civil War reformers (Eiselein 14). Even though her newsboys stories do show that she looked favorably upon their disciplining forms of employment, Louisa May Alcott was still influenced by her parents' model of "eccentric benevolence" (Eiselein 1-16), based on a "less coercive" form of reciprocation between the philanthropist and the powerless (Eiselein 14). In contrast with the emerging model of organized philanthropy, her parents aimed to bridge "the hierarchical distinction between powerful persons who bestow assistance and weaker persons who merely receive it" (Eiselein IX).

\section{On Temperance Errands}

13 Though hardly compatible with her role as a provider, charitable pursuits soon emerged as a central concern when Alcott set up a project for a Christmas book on the city. And while she aspired to the wisdom of a mature, altruistic Aunt Jo, Louisa never completely suppressed the restless, tomboy individualism of her younger alter ego, Jo March. On the contrary, even when the benevolent genre conventionally required a sentimental and moral stance, Jo occasionally resurfaced, for example in the form of the resourceful "little women" who, in Silver Pitchers' eponymous tale, defeat the alcohol abuse that threatens the male members of their families.

Even though her father Bronson "disdained liquor" and her abolitionist uncle, Samuel Joseph May, was a temperance advocate, Louisa did not abstain from alcohol herself and, as Jessy Randall recalls in an entry on "Temperance" (Eiselein and Phillips 322), she was nicknamed Sairy Gamp, after Dickens's drunken nurse. In Victorian times, temperance was not only a little debated component of the most sanguine anti-slavery activism (as illustrated by temperance champions William Lloyd Garrison or Louisa's uncle Samuel Joseph May ${ }^{5}$ ), but a leading theme in popular fiction. Therefore, when Daniel Ford, the publisher of The Moderate Drinker, asked her to write a Christmas book (to be run initially as a series in The Youth Companion in 1875), she opened the volume with a long tirade against the dangers of liquor, which was no less socially harmful and reprehensible than child labor. And since lemonade and plain water were the harmless Victorian antidotes to alcohol, Louisa May Alcott took up on Rebecca Harding Davis's social agenda by turning the latter's water-filled "Earthen Pitchers" into precious and shining Silver Pitchers. Their silvery beauty cheerfully hints at the sparkling nature of Alcott's temperance crusade, making her reforming mission comparatively more joyful and entertaining than Davis's meagre prescriptions. Like the temperance army of the three girls who, in the cover story, graciously dispense reforming lessons along with 
detoxifying goblets of water, Alcott makes Davis's modest and dull earthen pitchers tinkle with a more elevated metal, "for the Christian graces quite outdid the earthen ones" ("Silver Pitchers" 7). Therefore, it can be argued that in the stream of Victorian temperance literature, Alcott stands midway between Davis's proletarian austerity and Nathaniel Hawthorne's kingly "Golden Touch," which, in his retelling of the famous Greek myth, paralyzes thirsty Midas. Her "jollier" alternative seems by far preferable to the modest but healthy "earthen pitcher of water" (Hawthorne 77) that quenches Midas's thirst for the insensible "riches which so many mortals sigh and struggle after" (75).

15 The different materials chosen by the three Victorian American writers for their healing pitchers allogerically reflect their different aesthetic approaches to the reforming theme of temperance: reflecting Hawthorne's ingrained Puritan frugality and moderation, gold is ultimately cursed, and Davis's bare "earthen" jug likewise speaks to a proletarian economy of mere subsistence unlikely to appeal to large audiences. As for Alcott, she had just started enjoying the material benefits of her indefatigable literary career and was therefore well attuned to the poor's aspirations to material comfort: aligning her sympathetic model of temperance with Bronson Alcott's liberal pedagogy, she aimed to not only instruct, but also amuse and gratify her readers.

That Louisa May Alcott chose to open her narrative with a temperance tale is especially significant since, as mentioned above, her trip to the city had been planned with her parents after months of drug-related fits and unrest. Before reaching New York, she had long been pale, sick, sleepless, and no less moody than the protagonist of "Anna's Whim" (1873). In her early Gothic fiction, opium addiction was an ever-present Faustian metaphor, apparent in long-submerged anonymous thrillers like The Marble Woman, or The Mysterious Model (1865) and Perilous Play (1876) - both of which testify to the Goethean literary ambitions inherent in the author's "alternative" interest in intoxicating passions and in the sensational, "unwomanly" theme of female power. Once in New York, she was literally mesmerized by Moncure D. Conway's lectures on demonology, which only few years later inspired her anonymous thriller A Modern Mephistopheles (1877)-in all likelihood, the book on the Romantic notion of Genius which she had long been planning (Stadler 765 fn. 3, 660). ${ }^{6}$

By adopting a redeeming, female perspective on the subject, A Modern Mephistopheles (run anonymously in the "No Name series" published by Roberts between 1879 and 1887) questions the prevailing vision of genius as the product of male individualism-by contrast with the selfless dedication of the female philanthropists who led her on a tour of the city's benevolent institutions. Since Alcott's concern had always been to conquer her impulsive, "sensational" self, her late turn to reform literature and her desire to complete the edifying biography of her altruistic parents were quite at odds with the romantic notion of talent as that self-exalted and accursed condition which she identified with Goethe's Faust. Along this dual path of domestic duty and female creative power (one, she imagined, oscillating between damnation and redemption), ${ }^{7}$ she had finally secured the comfort to live by her pen. But in her urban quest, she further delved into that moral dilemma, in the very same weeks embarking on her search for a notion of female genius exempt from demonic temptations and attending the lectures of the abolitionist exile and occultist Conway. In that respect, the benevolent trip taken in homage to her parents" philanthropism became an "eccentric 
venture" (Eiselein 15) whose excitements informed both her anonymous Faustian novel and her fictional but dependable reports on the benevolent ventures of the local social workers.

Devoid of moralism or pathos, her tales' underlying realism was not just suited to her vivid sketches of the many charities, hospitals, and orphanages which she visited, it also allowed the author to come to terms with her own experience of destitution. Especially in her visits to the newsboys' shelters, Alcott assumed a Christian and compassionate attitude very similar to her parents' who, in their charity efforts, inspected the poor without ever passing judgment, bestowing comfort and affection rather than moral lessons. ${ }^{8}$ Throughout her visits, the writer's thoughts constantly went to her mother-a devoted, pious woman who provided Boston's poor with food and board even when she struggled to provide for her own family. ${ }^{9}$

When Silver Pitchers was published, Alcott might thus have felt she had completed at least part of her biographical project on Abigail May who, despite her poor regard for Irish Catholic maids, had helped them throughout the immigration emergency back in the 1840s. Her intention to celebrate her mother's philanthropy and her father's liberal pedagogy in support of the poor and the disenfranchised of all colors and backgrounds never materialized in a full biographical volume, but it does emerge from the sketches and fictionalized reports which she felt compelled to write upon her mother's irreversible illness. When she died in 1879, Louisa dedicated to her another short portrait as the quasi-anonymous but admirable "C." in "My Girls" (vol. IV of Aunt Jo's Scrap-Bag). Third in the list of her six favorite girls, Abigail May was described in perfect Little Women style ${ }^{10}$ as a natural reformer always willing to trade her privileges for the company of the poor. A distinguished heir to the Quincys (the heroes of the American Revolution whose centennial had just been celebrated) (Saxton 2), Abigail remained through her troubled life a fervent suffragist and Christian reformer ${ }^{11}$ who sought no public or financial recognition for the volunteer work offered "like an angel [...] to those who sat in darkness till she came to lift them up." Therefore, she spoke for all the domestic heroines who "are able to work better in a private way, and want no thanks for what [they] do" ("My Girls" 15). In this portrait, her daughter underlined that "womanly labor of love, so delicately, dutifully done"-and with utmost discretion, too. Her door-to-door methods preserved the privacy and anonymity of the poor "[s]o quietly, so tenderly, that only those saved knew who did it, and such loyal silence kept, that, even among the friends, the names of these unfortunates were not given, that the after life might be untroubled by even a look of reproach or recognition" (16). This benevolent rhetoric also extolled the female virtues of her father Bronson-whose proto-Marxist experiments (such as sheltering Black fugitives or supporting the suffragist cause) all contributed to his ostracization and perceived "emasculation."

Further intensified by Abigail's impending death, Louisa's disinterested charity rounds gave her benevolent tales that unique homely touch which made the fortune of the March saga. As a result, despite its prevailing didactic tones, Silver Pitchers deploys the same domestic economy of affection and female care on display in Hospital Sketches, which she based on her experience as a nurse in a Civil War camp hospital. At a time when "[d]ress was an all-absorbing topic" to most girls, as Alcott writes in "Sophie's Secret" (365), Louisa praised the "unfrivolous" economy of frugality ${ }^{12}$ which urged her mother to replace the fashionable lifestyle of her distinguished relatives with the simpler, but solid principles of her humanitarianism. In the same spirit, the 
autobiographical narrator of "An Evening Call" (originally published in The Youth's Companion, April 13, 1876) happily trades a Christmas shopping tour in New York for a charity visit to the Newsboys' Lodging House and School. ${ }^{13}$

Long respectably poor herself, never did Alcott identify with the army of middle-class "fairies" who periodically dispensed soup and sympathy "along with a heaping dose of moral instruction." ${ }^{14}$ Testifying to their remoteness from the kind of institutional philanthropy that their daughter later discovered in New York, Abigail May and Bronson Alcott professed a "practical Christianity" which operated on a civic, voluntary basis-even though they failed to offer sufficient relief to spare their own daughters the Victorian horrors of child labor. ${ }^{15}$ Despite the luxury of a transcendentalist education alongside literary geniuses like Henry David Thoreau, Ralph Waldo Emerson, Margaret Fuller, and Elizabeth Peabody, as a girl Louisa was sent to work as a servant in James Richardson's rural household in Dedham for seven long weeks. There, she was victimized by her master, as she reports in "How I Went Out Into Service. A Story" - a tale begun in 1862 and partly incorporated in the novel Work (also published in The Independent, vol. XCVI, no. 1331, June 1874, p. 4). As a result of this humiliation, Alcott found herself excluded from genteel circles, where many prejudiced benefactresses equated poverty with ignorance-in complete disregard for the Alcotts' well-read, cultural exposure to the best minds of their generation. Thus, despite their limits and many failings toward their children, the writer never dismissed the Christian charity model of her liberal parents, whose unconditional dedication to the disenfranchised opened new hopes of economic advancement for all, including African-Americans.

In another mid-1870s semi-autobiographical story humorously titled "Tribulation's Travels" (The Youth's Companion, Boston, Thursday, January 21, 1875, p. 17-18), Alcott, in her typical bittersweet and unladylike tone, ironically recalls when, as only a toddler, she had strayed into the dirty Boston streets, her parents being too absorbed in their charity efforts to even realize her disappearance. And since charity work and liberal education were a priority to the Alcott family, pretty soon all the financial burden fell upon their second daughter who, in an generous tribute to her father's transcendentalist pedagogy, dedicated to him her Little Men: Life at Plumfield with Jo's Boys (1871). New York's public custodial institutions still reflected the Victorian norms of the antebellum justice system which, in its lack of clear distinction between crime and poverty, invariably imprisoned the insane and the insolvent, as Dickens's life and narratives also showed. Before Louisa's New York tour, in The Hidden Hand or, Capitola, the Madcap (1859), E.D.E.N. Southworth had already stressed the reclusive nature of shelters for destitute children, in which the foundling Capitola would certainly have spent a long period of detention had Major Warfield not promptly appointed himself as her ward. ${ }^{16}$ Young New York vagrants like Capitola were brought before the Commissioners of Charity and assigned to homes for abandoned children, as at Blackwell's and Randall's Islands, where they learned various trades. In those institutions, skilfully captured by the illustrations of Harper's (Fig. 1 by Paul Frenzeny in Harper's Weekly, January 30, 1869, reprinted in Grafton 183), Alcott recognized domestic and hygiene practices from her own experience as a war nurse. Much like war hospitals before, correctional facilities were perceived as hotbeds of disease and disorder, thus requiring the presence of women: only they could apply the principles of domestic management and care that those environments sorely needed. 


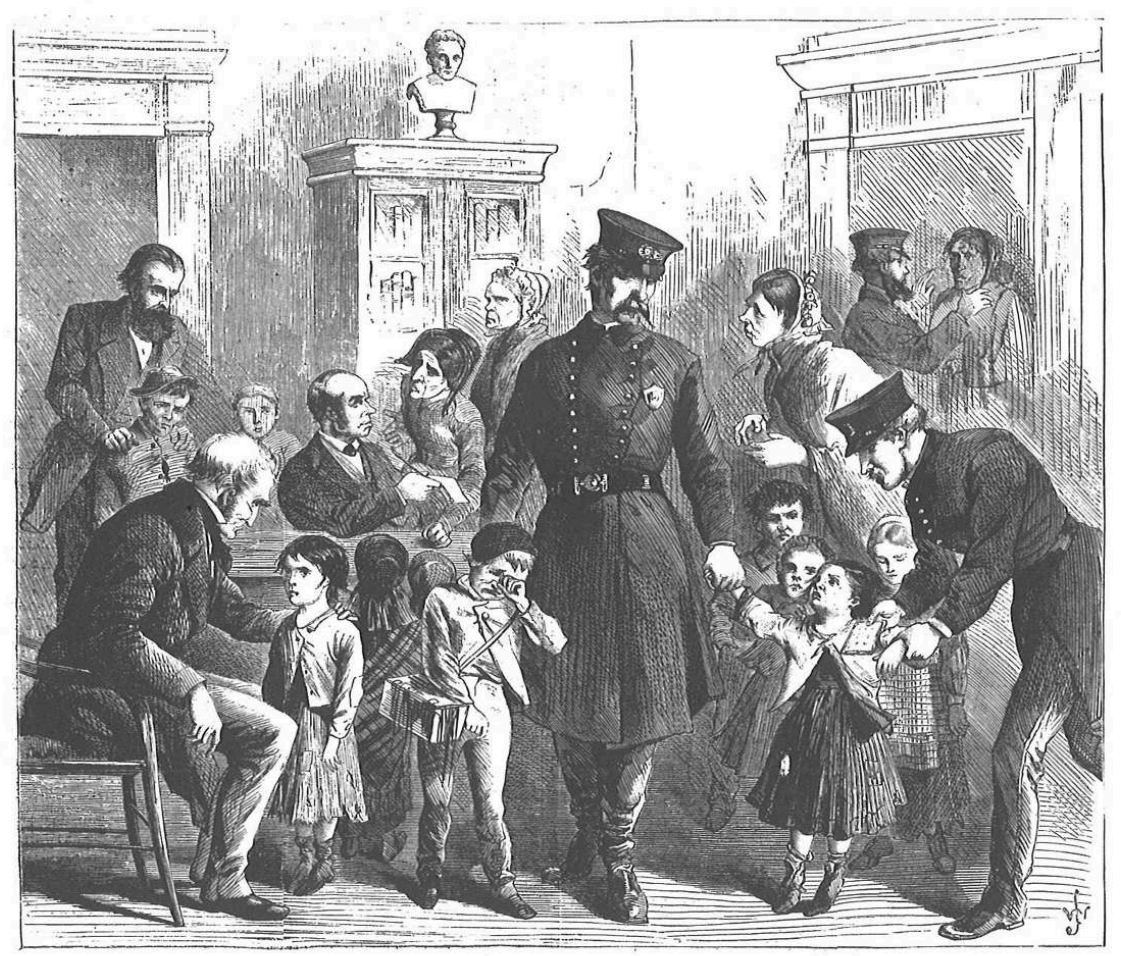

Figure 1: Illustration by Paul Frenzeny, Harper's Weekly, January 30, 1869

New York charities by many women reformers whose activism extended to abolitionism and women's suffrage, in a combination typical of anti-slavery activists such as Louisa's parents and uncle Sam, who all jointly espoused temperance reform and women's rights. Reflecting a connection between the Christian altruism, health and social reform, and feminism typical of Victorian benevolence, Louisa's guides in the New York underworld (temperance reformer and suffragist Zerilda Wallace, as well as former National Anti-Slavery Standard editors Anna Rice Powell and Aaron Powell) had all previously embraced abolitionism in their quest for egalitarianism. As the writer recalls in a letter to her mother on January 1-2, 1876 (Myerson and Shealy, 1995 21), her chaperone in New York's poorhouses Abigail Hopper Gibbons was not only the founder of the Women Prison Association in New York who ministered to the waifs on Randall's Island visited by Louisa on New Year's Eve, ${ }^{17}$ but also the daughter of the Quaker reformer Isaac T. Hopper, celebrated by Lydia Maria Child as "that indefatigable friend of the oppressed" who assisted "one of the innumerable tribes of fugitives from slavery" (Child, Letter from New York XI on December 9, 1841, p. 69).

As Gregory Eiselein and Monika Elbert argue in their research on the public management of charity in the Reconstruction era, Abigail May Alcott's door-to-door visits to her poor neighbors radically differed from the new modes of public charity which, starting in the second half of the century, was now being organized institutionally. While Louisa May Alcott's writings addressed those new forms of charity, Abigail May's social work and Bronson Alcott's Romantic pedagogy still provided a model of Christian charity that informed her tales on poor children. Her tales' rhetoric thus remains domestic in nature and largely informed by a public health system which, ever since the Civil War and Florence Nightingale's innovative nursing 
methods, had been transformed by women's presence. Nightingale had turned overcrowded and foul-smelling hospital wards into sanitized, homely environments-a humanitarian approach to emergency which now extended to the almshouses described by Alcott. Alcott adopted an equally benevolent and cheerful tone in her discussion of the harsh realities of juvenile delinquency and youth exploitation, a Dickensian compensatory strategy that was soon to become a hallmark of her acclaimed fictions for adolescents. Much in keeping with the attitudes of her alter ego Tribulation Periwinkle in Hospital Sketches and, later on, none other than her Little Women, Victorian America's social ills are mitigated through the reassuring presentation of orphanages and shelters as nothing short of surrogate families, providing orphans with unfailing educational and emotional support.

In the opening chapter of Little Men, the foundling Nat, abused by his Italian master Nicolo, instantly finds his new home in Plumfield, the orphanage inspired by Bronson's Temple School: there, the young street musician breaks from social isolation, as his schoolmates urge him to take the fiddle and make a show of his genuine musical talent. ${ }^{18}$ Conceived by Alcott shortly before her benevolent tales, this episode (which opens the March saga's second volume) anticipates themes later explored in a Harper's illustration, where a cruel master flogs a young fiddler (fig. 2 by A.Goult and B. Mayrand, in Harper's, September 13, 1873, reprinted in Grafton 56). Linking mass migration with the rise of young vagrants, both the illustration and Little Men display the same prejudice against Southern European immigrants, here invariably represented as enslaving masters. Set in a dreary tenement room, the engraving features a crate of macaroni fresh from Naples, a number of graffiti (including such misspellings as "Eviva Italia"), complete with a whole crew of young street musicians who, folk instruments still in hand, watch as their companion is flogged mercilessly. Appropriating Alcott's dramatic presentation of abused streetboys, the engraving builds on Alcott's narrative of the young street musician kidnapped or purchased in Italy and forcibly brought to New York to enrich his cruel master.

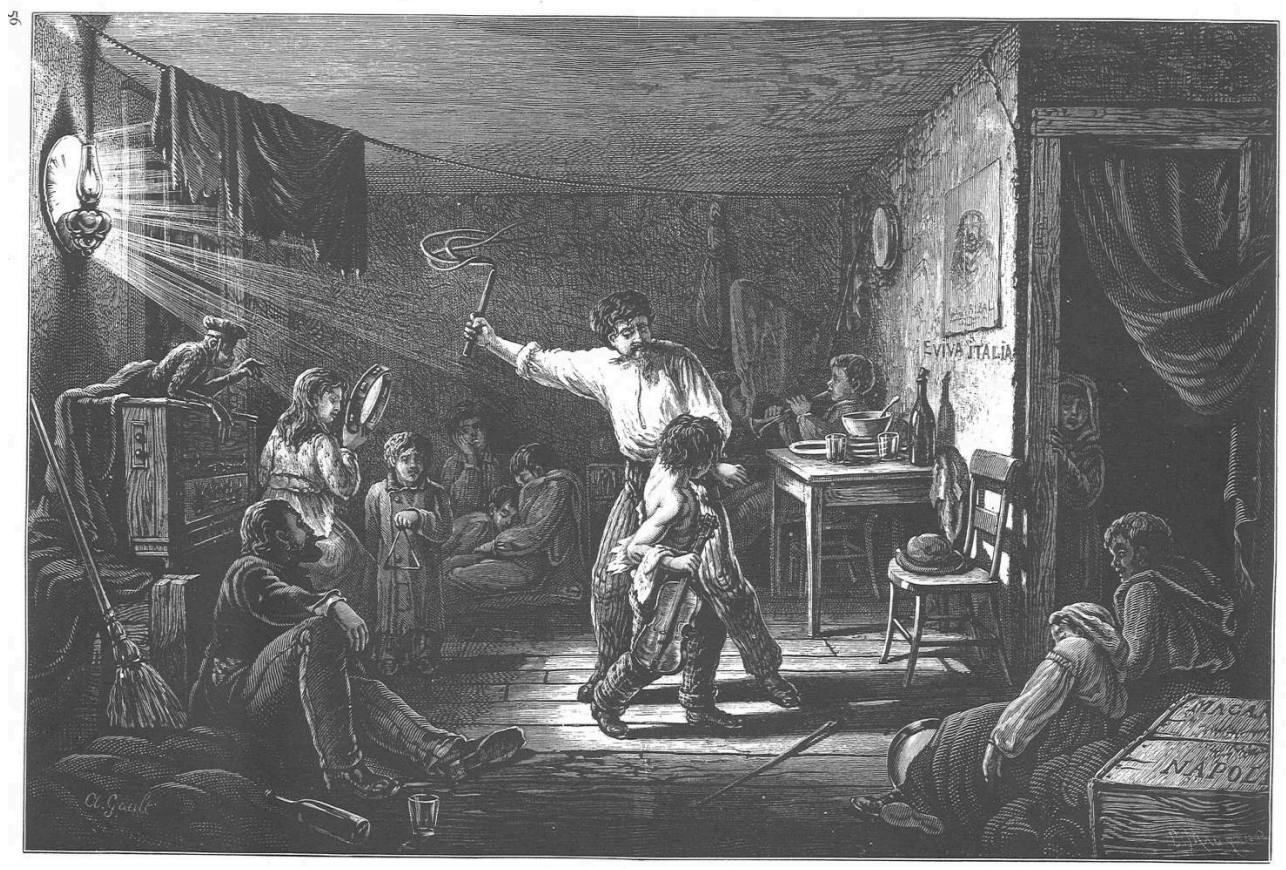


Figure 2: Illustration by A. Goult and B. Mayrand, Harper's Weekly, September 13, 1873

Other stories by Alcott on Italian-born street singers appeared under the titles of “Tessa's Surprises," in a 1868 issue of Merry's Museum later illustrated in the first volume of Aunt Jo's Scrap-Bag (fig. 3, vol. I, 1880, p. III), and "Music and Macaroni” (Lulu's Library, 1889 92-141). Once again, the young street musicians' rather small gratification is an invitation to sing and play at a wealthy girl's birthday party, much in the way that the boarding-school run by Aunt March and her husband in Little Men (1871) triumphantly puts the orphan Nat center stage as a skilled violin player. Both episodes evince a recurrent, structural pattern central to the March saga-a sentimental theme of Christian redemption which, as with Dickens, only minimally compensates for the worst cases of destitution and social injustice. This paternalistic spirit of redemption was very much in line with the Alcotts' domestic philanthropism which, based on personal contact, door-to-door charity work and physical proximity, eventually caused the fatal infection of their daughter Elizabeth. ${ }^{19}$ In a mirror gesture of her mother's own hugging ritual, Louisa, in her neighborhood charity rounds to New York's new custodial institutions, did not hesitate to hold the young orphans in her arms or bring them toys and candy to make her visist a memorable occasion.

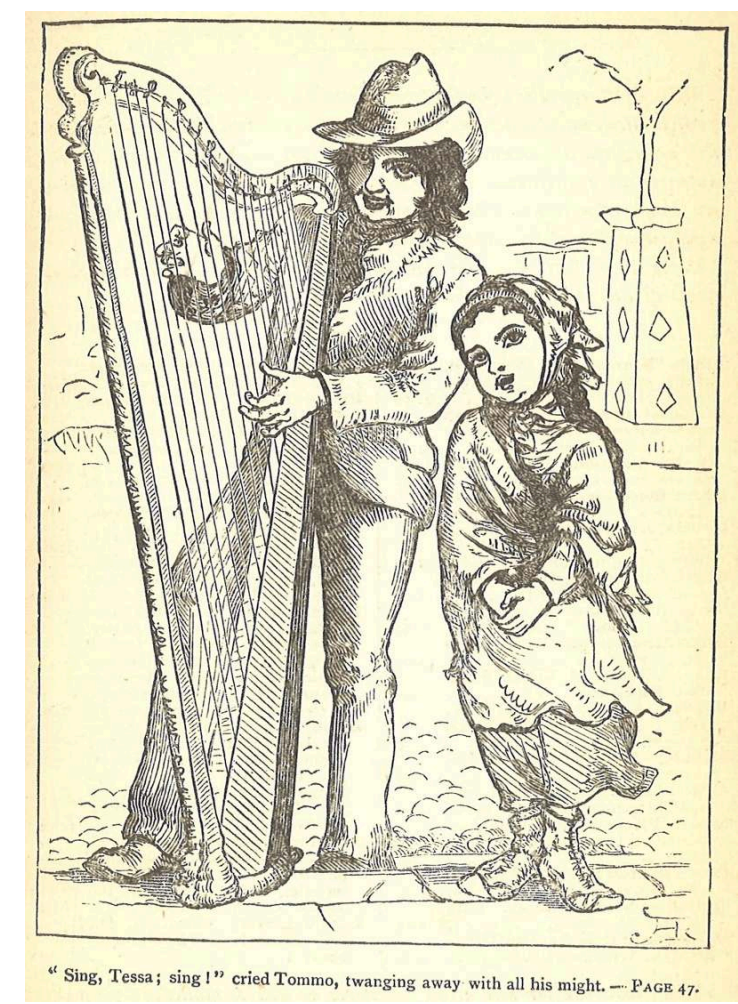

Figure 3: Illustration from Aunt Jo's Scrap-Bag, vol. I, 1880, p. III

\section{Charitable Proto-Taylorism: The Newsboys' Home}

As Monika Elbert explains, from the Reconstruction era on, the heartless, integrated system of sheltering and surveillance imposed the factory's exhausting, mechanical rhythms upon almshouses, in a radical departure from the Alcotts' own charity practices. In her exploration of the public benevolent institutions, Louisa's choice was 
to preserve the warmth of her parents' charity, with none of the controlling and inspective attitude typical of the modern, professional social worker. As a secondgeneration transcendentalist, she never fully converted to the spirit of entrepreneurial efficiency. In her mind, the shelter did not provide a mere refuge for the abandoned, but a semblance of family bonds increasingly threatened by the new, aggressive economic system.

Without invalidating the humanitarian practices inherited from her parents (whose educational liberalism was based on the Rousseauian idealization of childhood), ${ }^{20}$ what the writer witnessed in New York City was a dramatic change in social welfare policies, with the rapid proliferation of "institutional philanthropies, variously termed curative, preventive, repressive, and reformative" (Christianson 2). Disguising its didacticism under the trappings of urban sketches and children's tales, Silver Pitchers illuminates the proto-Taylorism of the postbellum benevolent machinery, at a time when the Alcotts' interpersonal philanthropy was being replaced by state control over deviance and poverty. The modern poorhouse's entrepreneurial model required that the young wards work and invest their way up the social ladder, turning the sheltered orphans into low-wage workers expected to sustain the profitable banking system run by the orphanage itself. ${ }^{21}$ Masquerading as Horatio Alger's rags-to-riches American myth, this managerial version of Victorian pauperism reinforced an industrial, profit-oriented model of charity dwellings, encouraging young workers to save and invest their earnings in the very public institutions that disciplined and confined them. The atrocity of the banking saving system in use at the Newsboys' Lodging House in Duane Street has been stressed by Karen Sánchez-Eppler, who first related Ragged Dick's entrepreneurial model to the rationale of Alcott's "An Evening Call": "In the process of these novels, Alger's boys learn to save in newly opened bank accounts, and to spend the cash they accrue not on swiftly consumed pleasures, but on more lasting markers of status and domesticity: suits of clothes and regular beds." ${ }^{22}$ As Sánchez-Eppler significantly recalls, A.K. Loring used to "send a gratuitous copy of the two volumes of Ragged Dick to any regularly organized newsboy's Lodge within the United States" (Sánchez-Eppler 171).

30 Founded by the Children's Aid Society, the gruesome Newsboys' Lodging House depicted in "An Evening Call" imposed upon its young residents an adult model of fast growth and social self-promotion. In that total institution, food, accommodation, and banking were arranged in one and the same location, borrowing directly from the allencompassing, centralized "social home" devised twenty to thirty years earlier in Catharine E. Beecher's 1842 Treatise on Domestic Economy. Indeed, both the modern orphanage and the social home reflected a triumphant domestic ideology which conceived the household as a woman-managed space accommodating work, school, and housing. In the Gilded Age, the new policies of hygiene and control over society's outcasts fell under the female-managed category of domestic discipline. And much as Beecher's domestic ideology provided a comprehensive model of social organization regulating the collective, emotional, and social aspects of human life, so did the newsboys' dorms in the 1870 s constitute microsocial enclaves whose self-contained economy turned the domestic sphere into a productive enterprise regulated by social workers. Therefore, while in Beecher's domestic theory a home simultaneously operated as a shelter, a school, and a temple, the Newsboys' Lodging House pushed her all-encompassing vision one step further by incorporating a banking facility, as Alcott 
did not fail to note during her visit. More attuned to capitalist than philanthropic values, those dorms turned residents into literal "business boys," in Alcott's bittersweet expression ("An Evening Call" 257). As a result, the former Christian charities turned from non-profit organizations into miniaturized social laboratories of economic growth, which entailed working, saving, and investing. The coercive aspects lurking behind this modern urban charity could not have escaped the business-conscious Alcott who, as a best-selling author, had always been a shrewd manager of her fortune. Yet, even on these occasions, she cast a controversially bright light on the forced enrollment of children, which made orphans mere cogs in the larger machinery of industrial labor.

31 When Alcott set out to visit the Newsboys' Home, her self-professed jolliness and business-like attitude allowed her to turn a blind eye to the boys' material pain and strain-or even brush aside her own surprise to find a bank in lieu of the expected school:

So arrangements were made, and one cold evening we set out to see the boys in the Newsboys' Lodging House. We arrived just too late for the evening school, but I was quite resigned to that because I could see schools anywhere, but not a hundred and eighty independent business boys "taking their ease at their inn." All around the great hall were rows of little cupboards, and it was a fine sight to see a boy come in, pay six cents for his lodgings, put his surplus funds into the saving bank, register his name, receive his key, and leisurely deposit his cap, racket, and shoes (if he possessed any of these articles) in his own private cupboard. One lad had nothing but an old cap, yet he laid it away and locked it up with such an air of satisfaction and importance that it did one good to see him" ("An Evening Call" 257).

Alcott's account of the multiple activities that make up the newsboys' daily life closely parallels C.G. Bush's illustration of assemblyline-like sequence of vignettes drawn from the very same institution (fig. 4, Harper's Weekly, May 18, 1876, in Grafton 52).

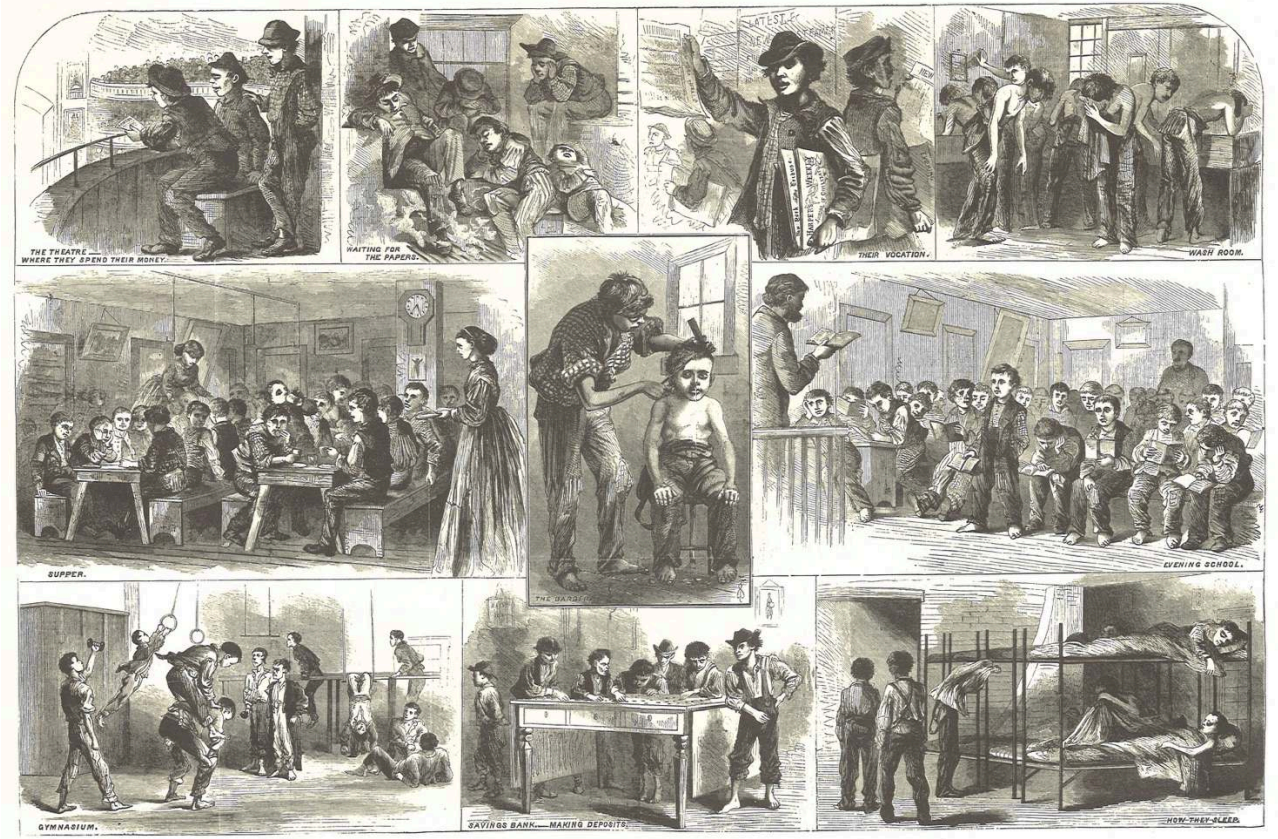

Figure 4: Illustration by C.G. Bush, Harper's Weekly, May 18, 1876

Located above the Sun's offices in Fulton Street, the Newsboys' Home charged the sheltered orphans a nominal amount of four cents a meal and five cents for a bed. 
Needless to say, Alcott showed a sincere empathy for those struggling little workers, whose wish for independence aligned with her transcendentalist ethos of self-reliance. As a modern entrepreneuse of the Gilded Age, the writer really struggled to accommodate capitalism's aggressive features with the humanistic values of her philanthropic legacy. Accordingly, she describes resourceful children-laborers as precocious providers with whom she easily identified, having been forced in that role by her ineffectual and often absent father. Therefore, as in her earlier fictional portraits of little women burdened by adult responsibilities, her Newsboys Home tale celebrates the miniature society of the young unfortunates who pay for their food and lodgings as independent, finance-conscious executives. As for the grim parody of the shelter's banking institution, the writer did not regard it as yet another instance of oppression from an institution that visibly inspected every single moment in the poor boys' lives, but rather approved its panoptical mixture of confinement and discipline, of poverty and profit. Projecting her own work ethic onto the shelter's wards, Alcott did not detect quiet desperation in their eyes, but rather the signs of their potential as productive individuals, reflecting the Reconstruction-era belief that poverty and exploitation could be effectively fought through the educational influence of such correctional establishments. And while in her mind the Tombs remained a hopeless prison for unredeemable prostitutes and criminals, in "A Visit to the School Ship" (first published in the Merry's Museum in March 1869), she finds the employment imposed on poor children and juvenile delinquents a valid path toward self-betterment. In other words, the author found those reformatories fit for the Gilded Age's new era of production and thus very likely to safely bring this correctional boat "into port." ${ }^{23}$ As Eiselein and Elbert alert us, those reforming institutions were indeed instances of the proto-Fordist rationalization of child labor which, despite the sweetening effects of Dickens's and Alcott's rhetoric, displayed a repressive nature far removed from their self-professed advantages. In this respect, the benevolent corners depicted (and, in many ways, advertised) by Alcott, expanded on the dynamics introduced by Charles Loring Brace's mid-nineteenth century Orphan Train Movement, which deported young individuals charged with disorderly conduct to Western regions, where they were to settle and contribute to America's colonizing process at their own risk and cost. ${ }^{24}$ In other words, the institutional control on those children appeared absolute and quite alien to the Alcotts' disinterested philanthropic legacy. Though cheerful and optimistic in appearance, Alcott's urban sketches did not conceal from the reader's eye the unequivocal financial control exerted over the poor boys' meagre earnings, allowing them to be reconsidered as veiled tragic comedies. Their hidden satire documents the rise of the third sector, at a time when big city charities were turning into a bureaucratized machinery of control of the disenfranchised, whose purpose was to monitor and channel the productive energies of the urban delinquents and vagrants. As the popular author of more than three hundred titles, Louisa herself embodied the American promise of social uplift through hard work, and readily endorsed the new public orphanages as vehicles for their wards' future material success.

At the same time, Louisa May Alcott could not ignore the disciplining and coercive implications of that new entrepreneurial system, which fined the poor orphans in proportion to their late arrival in the dorm after their day's work and forced them to deposit their meagre earnings in a bank run by their institutional landlord. However, her miraculous rise in the bookmarket persuaded her that wealth-or even the illusion of owning something-could boost the spirits of the young destitutes whom she 
described as the philanthropic corporation's full time "employees." By this perverse logic, the bank symbolically served as the most titillating facility for the distressed children, whose working, religious, and private lives were rigidly monitored and regulated, and whose only real financial power was to trade their assigned vittles and feast in town for their private little money. ${ }^{25}$

It goes without saying that the pressing demands for production and capitalization placed upon the impoverished street-boys dulled their natural exuberance, precluding the athletic and outdoor activities recommended by Bronson Alcott's liberal pedagogy as a playful incentive for the development of more spontaneous habits of industry (169-170). Calling on her father's Rousseauian educational ideals for the training of body and mind, Alcott claimed that sports would offer some release from the institution's restrictive order and the "soaring ambition" so prematurely forced on them. Celebrating the memory of her own healthy, unrestrained, and uncorseted youth, ${ }^{26}$ Alcott wrote "A New Way to Spend Christmas" (first published in the Youth Companion in March 1879) as an homage to a correctional pedagogy that exercized rather than brutalized the body. ${ }^{27}$

Bronson Alcott's radical idealism was incompatible with the surveillance strategies enacted by New York's industrial charities, whose plan to make worthy poor out of homeless street vendors was diametrically opposed to his uncommercial and protosocialist views. Yet, in "My Rococo Watch" 28 (which she wrote right before her New York tour), Louisa May Alcott appears both repelled and seduced by the new mercenary advertising practices, and quite torn between her parents' transcendentalist ideals and the entrepreneurial spirit of postbellum America.

Never too concerned with surveillance, in her visit to the newsboys' shelter, she recorded the strict schedule which mechanically determined even the scant time that the little inmates had for cleaning and reading (skilfully illustrated in fig. 4), seemingly endorsing the proto-Taylorist practices which underlay the newly professionalized philanthropy and its "objectifying" policies (Elbert 20-21). As she turned her reports into fiction, Alcott could not help but offer a hopeful account of these disciplining establishments, downplaying the controlling aspects of the inmates' semi-detention or the social humiliation inevitably induced by poverty. Her special empathy for difficult adolescents enabled her to portray even the most socially disadvantaged orphans as sharp, tidy "little men," dressed in unpretentious but decent clothes. ${ }^{29}$ And, with the typically joyful and sympathetic tone of the "little woman" writer, she romanticized the underprivileged condition of those unfortunates, casting on them a beam of light no different from that which surrounds the respectable poverty of the March sisters. Emphasizing the rosier aspects of their "advancing" condition, she optimistically concludes: "This arrangement encourages industry and economy, yet leaves the lad quite independent, and that suits the masculine mind, however young or ignorant" (“An Evening Call" 261).

Neverthless, even in her general praise of pseudo-humanitarian institutions, she never failed to note the weariness in their eyes, due to their precocious exposure to the profit-making machinery. And a December 25, 1875 letter to the Saturday Evening Post sadly captures "the dumb delight of their unchild-like faces trying to smile" (Myerson and Shealy, 1995 213). The writer thus critically identifies "One little chap of six [...] trotting about among the larger boys, as busy as a bee with his small affairs" ("An 
Evening Call" 258), unnaturally absorbed in the miniaturized version of an adult profession.

The little criers featured in "An Evening Call" are too evidently exhausted and distressed from their long working hours in the streets to even care to fret and caper as other boys naturally would. Still proud of her own tomboyish restlessness, Alcott catches them in a rare moment of pause before sleep, well aware that while their weariness from toil might keep them away from street delinquency, ${ }^{30}$ it did not compensate for their lack of a mother's touch. ${ }^{31}$ In a compassionate gesture reminiscent of her parents' close contact with the disempowered, the author tucks their coverlets, as she once did with her patients in wartime. ${ }^{32}$

"An Evening Call," Alcott's most accomplished and discussed benevolent tale, dialectically shifts from her edifying account of modern charity to the pathetic episode of the nine-year-old boy who, looking after his younger sibling, tries to spare him the horrors of child labor. It was Mrs C.O. O'Connor who, leading the distinguished writer on her tour of Newsboys' Lodging House, pointed out a pair of siblings whom the institution worked hard to keep together. On December 4, 1875, Alcott sent a lively report on that episode to her nephews, ${ }^{33}$ soon to become central to "An Evening Call"so moved was she that even the dreariest conditions of solitude and abandonment could nourish the authentic affection and care of a devoted brother: "The idea of this child knocking about at night in the busiest places and coming in, tired out, to pay for 'self and family,' like a little man, was so comic and so pathetic that it quite haunted me for days afterward and I longed to see and know both the boys and learn how they turn out in the years to come" ("An Evening Call" 258).

In this extraordinary Christmas tale, a child worker instinctively detects his brother's presence in the midst of a crowd of orphans, casting a reassuring, sentimental light over the existential drama of New York's poor children. Much in keeping with the pathetic mode typical of Dickensian fiction and of the Victorian rhetoric of benevolence, the desolate dorm magically turns into a surrogate home, complete with loving family relations..$^{34}$ In these moving and affective moments, Alcott's portrait of abandoned children effectively defuses their condition as laborers, turning the dreary dormitory into a family-based corporation designed by the Aid Society for the protection (and not the mere simulation) of family relations, in keeping with women's domestic ethos. Providing a counterpoint to the pervasive ideology of survival and competition, the episode of Patsey-the infant affectionately fathered by his older brother-points to the apparent conciliation of brotherly love and Christian charity with the entrepreneurial values of modern philanthropy. In addition, this caring gesture allows Alcott to endow her characters with inner lives, individualizing their pain rather than casting them as indistinct objects of pity. ${ }^{35}$ In paying for his younger brother's living expenses, the nine-year-old avoids his adoption by strangers and casts a human light on a charity designed as a 24-hour enterprise to turn young orphans into a new generation of law-abiding citizens and worker-investors. ${ }^{36}$

41 No doubt reminding Alcott of her own difficult progress into adulthood, those destitute children urged her to provide her audience with a glimmer of hope and make herself a living example of self-betterment through self-reliance. Yet, on the whole, their Bildung remained no less traumatic than the one recounted by Charles Dickens and Hans Christian Andersen. Alcott's bitter-sweet version of these public and private Victorian horrors is therefore constantly darkened by an ambivalence which, by 
alternating comic and pathetic scenes, underlines the injustice of children forced into adult responsibilites. In this respect, Patsey's clothes are especially revealing: much as his trousers are ominously "built for larger men," ${ }^{37}$ so are young laborers deprived of playfulness and consumed by the Reconstruction Era's Darwinian struggle for survival (Hofstadter 41 quoted in Elbert 22).

In her jointly black humorous and pathetic treatment of their confinement, Alcott skilfully embraced Dickens's formula of a light-hearted account of tragic situations. Her brisk, sketchy realism allows the bitterest injustice and exploitation to be euphemized and easier to process even by young audiences. By re-elaborating the urban hardships that she witnessed in sentimental scenes and didactic sensations, Alcott spared her readers the crude naturalism which, taking its cue from Rebecca Harding Davis, later flourished at the turn of the twentieth century. We cannot be sure whether Alcott intentionally adopted a tongue-in-cheek tone to mitigate the dispiriting realism of reform literature. The fact remains, however, that her stylistic ambivalence enabled her to bring a human touch to the imperatives of profit and commerce which in so many ways marred her late narratives. Yielding to her own financial anxieties as well as to the pressure of both her publisher and her family, in her New York sketches she readily identified in her own oppressive writing overload as the primary cause for the defects of her late production.

\section{BIBLIOGRAPHY}

\section{Works by Louisa May Alcott}

“Anna's Whim.” The Independent, vol. XXV, no. 1291, 28 August 1873. Reprinted in Silver Pitchers, and Independence: A Centennial Love Story. 1876. Boston: Roberts, 1888, p. 47-78.

“An Evening Call." The Youth's Companion, vol. XLIX, no. 15, 1876. Reprinted in The Sketches of Louisa May Alcott. Ed. Gregory Eiselein. New York: Ironweed Press, 2001, p. 257-262.

Hospital Sketches. Boston: Redpath, 1863.

"Gossip." Little Women, part II. 1869. Reprinted in Works of Louisa May Alcott. Illustrated and Unabridged. Ed. Claire Booss. New York: Avenel, 1982, p. 191-199.

"How I Went Out Into Service: A Story." The Independent, vol. XXVI, no. 1331, 1874, p. 1-2. Reprinted in Alternative Alcott. Ed. Elaine Showalter. New Brunswick: Rutgers University Press, 1988, p. 350-363.

“Letty's Tramp." The Independent, vol. XXVII, no. 1412, 1875. Reprinted in The Woman's Journal, vol. VII, no. 5, 1876, and in Silver Pitchers, and Independence: A Centennial Love Story. 1876. Boston: Roberts, 1888, p. 177-204.

Little Men: Life at Plumfield with Jo's Boys. 1871. Reprinted in Works of Louisa May Alcott. Illustrated and Unabridged. Ed. Claire Booss. New York: Avenel, 1982, p. 392-594. 
“Mother's Trial.” The Youth's Companion, vol. XLIII, no. 21, 1870.

“Music and Macaroni." Lulu's Library, vol. III. Boston: Roberts, 1889, p. 92-141.

“My Girls.” 1878. Aunt Jo's Scrap-Bag, vol. IV. Boston: Roberts, 1889, p. 7-27.

“My Rococo Watch." The National Elgin Watch Company's Illustrated Almanac. Chicago: Culver, Page and Hoyne, 1875. Reprinted in Silver Pitchers, and Independence. A Centennial Love Story. 1876.

Boston: Roberts, 1888, p. 136-148.

“A New Way to Spend Christmas." The Youth's Companion, vol. XLIX , no. 10, 1876. Reprinted in The Sketches of Louisa May Alcott. Ed. Gregory Eiselein. New York: Ironweed Press, 2001, p. 250-256.

“An Old-Fashioned Girl.” Merry's Museum, July-August 1869. Reprinted in An Old-Fashioned Girl. Boston: Roberts, 1870.

“Silver Pitchers: A Temperance Tale." The Youth's Companion, vol. XLVIII, no. 18-23, 1876.

Reprinted in Silver Pitchers, and Independence: A Centennial Love Story. 1876. Boston: Roberts, 1888, p. 1-46.

“Sophie's Secret." 1873. First published in St. Nicholas, November-December 1883. Reprinted in Lulu's Library, vol. III. Boston: Roberts, 1886, p. 364-380.

“Tessa's Surprises.” Merry's Museum, no. 55, December 1868. Reprinted in Aunt Jo’s Scrap-Bag, vol. I. Boston: Roberts, 1880 , p. 34-57.

“Transcendental Wild Oats: A Chapter from an Unwritten Romance." The Independent, vol. XXV, no. 1307, 1873, p. 1569-1571. Reprinted in The Woman's Journal, vol. V, no. 8, 1874.

“Tribulation's Travels.” The Youth's Companion, 21 January 1875, p. 17-18.

“A Visit to the School Ship.” Merry's Museum, March 1869. Reprinted in The Youth's Companion, 24 May 1888, and The Sketches of Louisa May Alcott. Ed. Gregory Eiselein. New York: Ironweed Press, 2001, p. 225-230.

“A Visit to the Tombs." The Youth's Companion, vol. XLIX, no. 21, 1876. Reprinted in The Sketches of Louisa May Alcott. Ed. Gregory Eiselein. New York: Ironweed Press, 2001, p. 263-269.

\section{Other Works Cited}

AGAMBEN, Giorgio, Infanzia e storia. Distruzione dell'esperienza e origine della storia. Torino: Einaudi, 1978.

ALCOTT, A. Bronson. The Doctrine and Discipline of Human Culture. Boston: James Munroe, 1836. ALGER, Horatio. Ragged Dick, Or, Street Life in New York with the Boot Blacks. Boston: A.K. Loring, 1868. New York: Collier, 1962.

BEECHER, Catharine Esther. Treatise on Domestic Economy for the Use of Young Ladies at Home and at School. Boston: T.H. Webb, 1842.

BERGMAN, Jill, and Debra BERNARDI, eds. Our Sisters' Keepers: Nineteenth-Century Benevolence Literature by American Women. Tuscaloosa: Alabama Univesity Press, 2005.

CHILD, Lydia Maria. Letters from New York. 1843. Ed. Bruce Mills. Athens: Georgia University Press, 1999.

CHRISTIANSON, Frank. Philanthropy in British and American Fiction: Dickens, Hawthorne, Eliot and Howells. Edinburgh: Edinburgh University Press, 2007. 
DAVIS, Rebecca Harding. Earthen Pitchers. Scribner's Monthly, November 1873, p. 73-81; December 1873, p. 199-207; January 1874, p. 274-281; February 1874, p. 490-494; March 1874, p. 595-600; April 1874, p. 714-721.

DAVIS, Rebecca Harding. “The Harmonists.” The Atlantic, no. 17, 1866, p. 529-538.

EISELEIN, Gregory. Literature and Humanitarian Reform in the Civil War Era. Bloomington: Indiana University Press, 1996.

EISELEIN, Gregory, and Anne K. PHILLIPS, eds. The Louisa May Alcott Encyclopedia. London: Greenwood Press, 2001.

ELBERT, Monika. "Charitable (Mis)givings and the Aesthetics of Poverty in Louisa May Alcott's Christmas Stories." Enterprising Youth: Social Values and Acculturation in Nineteenth-Century American Children's Culture. Ed. Monika Elbert. New York: Routledge, 2008, p. 19-38.

ELBERT, Monika, and Lesley GINSBERG, eds. Romantic Education in Nineteenth-Century American Literature: National and Transatlantic Contexts. London: Routledge, 2014.

GRAFTON, John. New York in the Nineteenth Century. 317 Engravings from Harper's Weekly and Other Contemporary Sources. New York: Dover, 1977.

HAWTHORNE, Nathaniel. “The Golden Touch.” A Wonder-Book: For Girls and Boys. 1851. Boston: Houghton, Osgood, 1880.

HOFSTADTER, Richard. Social Darwinism in American Thought. Boston: Beacon Press, 1944.

LaPLANTE, Eve. Marmee \& Louisa: The Untold Story of Louisa May Alcott and Her Mother. New York: Simon \& Schuster, 2013.

MYERSON, Daniel, and Joel SHEALY, eds. The Journals of Louisa May Alcott. Boston: Little Brown, 1989.

MYERSON, Daniel, and Joel SHEALY, eds. The Selected Letters of Louisa May Alcott. Athens: Georgia University Press, 1995.

OLSEN, Tillie. “A Biographical Interpretation." Rebecca Harding Davis. Life in the Iron Mills, or the Korl Woman. Old Westbury: The Feminist Press of the City University of New York, 1985, p. 67-174.

RONELL, Avital. "Taking It Philosophically." Finitude Score: Essays for the End of the Millennium. Lincoln: Nebraska University Press, 1994, p. 129-158.

SÁNCHEZ-EPPLER, Karen. "Playing at Class." Dependent States: The Child's Part in Nineteenth-Century American Culture. Chicago: Chicago University Press, 2005, p. 151-185.

SAXTON, Martha. Louisa May Alcott: A Modern Biography. 1977. New York: Farrar, Straus and Giroux, 1995.

SHEALY, Daniel. “'Work Well Done': Louisa May Alcott and Mary Mapes Dodge.” St. Nicholas and Mary Mapes Dodge: The Legacy of a Children's Magazine Editor, 1873-1905. Eds. Susan R. Gannon, Suzanne Rahn, and Ruth Anne Thompson. Jefferson: McFarland, 2004, p. 171-188.

SOUTHWORTH, E.D.E.N. The Hidden Hand or, Capitola, the Madcap. 1859. Chicago: M.A. Donohue, n.d. STADLER, Gustavus. “Louisa May Alcott's Queer Geniuses.” American Literature, vol. 71, no. 4, 1999, p. 657-677.

VOGEL, M. Stanley. German Literary Influences on the American Transcendentalists. Hamden: Archon Books, 1970. 
WOMACK, Whitney A. “Reforming Women's Reform Literature: Rebecca Harding Davis's Rewriting of the Industrial Novel." Our Sisters' Keepers: Nineteenth-Century Benevolence Literature by American Women. Eds. Jill Bergman and Debra Bernard. Tuscaloosa: Alabama University Press, 2005, p. 105-131.

\section{NOTES}

1. The tales based on Alcott's re-appropriation of her family's benevolent legacy mostly appeared in The Youth's Companion, the children's journal, which she edited in 1868. "Silver Pitchers. A Temperance Tale" was first published in The Youth's Companion, vol. XLVIII, p. 18-23 (May 6, 13, 20, 27, and June 10,1875), later to be reprinted in the 1876 collection Silver Pitchers (Silver Pitchers; And Independence, A Centennial Love Story, Boston: Roberts, 1888, p. 1-46). In those days, "Letty's Tramp" appeared in The Independent, vol. XXVII, no. 1412 (December 23, 1875), later reprinted in The Woman's Journal, vol. VII, no. 5 (January 29, 1876) and in Silver Pitchers (1888, p. 177-204). An anonymous account of the orphans of Randall's Island was published with the title "Charity's Open Hand" in New York Daily Tribune, December 27, 1875, p. 5. Also based on Alcott's trip to Randall's and Blackwell's Islands, "A New Way to Spend Christmas" appeared in The Youth's Companion of March 9, 1876, reprinted in 2001 in The Sketches of Louisa May Alcott edited by Gregory Eiselein (250-256). "A Visit to the Tombs," the tale on the notorious New York prison, came out on May 25, 1876 in The Youth's Companion; "Helping Along," St. Nicholas, vol. III, no. 5 (March 1876), re-edited as "How One Sister Helped Her Brother" in The Christian Register, vol. LV, no. 24 (June 10, 1876); “Clams: A Ghost Story” appeared in The Youth's Companion of May 3, 1877; "Jersey, or, The Girl's Ghost" in the July 1884 issue of St. Nicholas. "Marjorie's Birthday Gifts" or "Helping Along" were respectively published in the January and March issues of St. Nicholas, while, among her Christmas tales, "The Boy's Joke, and Who Got the Best of It," was included in the Christmas Graphic, on December 22, 1875, p. 4-5. Two vivid accounts of Alcott's visits to orphanages had already been fictionalized in "A Visit to the School Ship," Merry's Museum in March 1869, reprinted in The Youth's Companion on May 24, 1888, and recently collected by Gregory Eiselein in The Sketches of Louisa May Alcott (225-230). "An Evening Call," which is the most critically debated of Alcott's benevolent tales, appeared in The Youth's Companion on April 13, 1876, later reprinted in The Sketches of Louisa May Alcott (257-262). Another autobiographical story served to prepare her benevolent tour: "Tribulation's Travels," The Youth's Companion, vol. XLVIII, no. 3 (Jan. 21, 1875).

2. After the enormous success of Little Women (1868), Louisa May Alcott was overwhelmed by publishers' requests and went on as an indefatigable writer aligned with the editorial imperatives of popular children's magazines like St. Nicholas. Specifically conceived to satisfy the growing female and youth audience, the "profusely illustrated" magazine was born in 1873 as a result of Alcott's friendly and productive collaboration with the editor, Mary Mapes Dodge, who worked with Alcott in a mutual "spirit of mirthfulness" (Shealy 171-188).

3. On this urban model of organized philanthropy, see the seminal volumes on benevolent literature in Victorian America by Gregory Eiselein, Jill Bergman and Debra Bernardi, and Monika Elbert. In their introduction to Our Sisters' Keepers, Bergman and Bernardi define benevolence as a social response to pauperism in Victorian America (4) which, as Eiselein also explains, later turned into a system of discipline and control. Alcott's New York tales endorsed such an oppressive system at a time when the writer had started considering her own career more as a profitable venture than an artistic calling. As a result of altruism and moral responsibilities conventionally attributed to American housewives and mothers, benevolence was a major theme in much of the coeval woman's literature. 
4. The generational gap between Alcott's transcendentalist legacy and the materialism that she developed in response to her family's financial inadequacy are satirically stressed in "Transcendental Wild Oats: A Chapter from an Unwritten Romance," The Independent, vol. 25, no. 1307 (December 28, 1873), p. 1569-1571. In that humorous reply to Rebecca Harding Davis's gloomy dystopia, “The Harmonists” (The Atlantic, May 17, 1866, p. 529-538), Louisa May Alcott objects to the domestic toil imposed upon the female members of her father's utopian community. Much as in Davis's tale, this community rested on the intensive domestic work of a neglected crew of empty-eyed wives and sisters, too exhausted to partake of the prophetic and intellectual elevation of its male founders.

5. In her December 1874 journal, Alcott writes that she was about to "get ready to do the temperance tale, for F[ord] offers $\$ 700$ for six chapters-'Silver Pitchers"' (Meyerson and Shealy, 1989 193). As Eve LaPlante recalls, in Louisa's eyes, her abolitionist uncle, Samuel Joseph May, was a pillar of strength and kindness. A father of five then in his early forties, he shared Bronson's views of racially integrated and coeducational schools, without being as difficult and cranky. His admiring niece later depicted him in "Gossip" (chapter xXIV of Little Women, part II) as "a quiet, studious man [...] busy with his [...] small parish [and] rich in [...] attributes." He "attracted to him many admirable persons, as naturally as sweet herbs draw bees. His wife was gentle and sophisticated. Their home was always noisy with antislavery talk and visitors 'black, white \& grey,' as her aunt Lu liked to say. Uncle Sam led prohibitionist parades of hundreds of children-his 'Cold Water Brigade,' as he called them-along Main Street carrying silk banners and chanting, 'So here we pledge perpetual hate! To all that can intoxicate!' and 'Cold Water is the drink for me!' At a public 'Execution of King Alcohol' on the town green, Uncle Sam wielded the ax. According to a local newspaper, 'Every rum-seller, in South Scituate capitulated before the Reverend May's moral weapons.' Best of all, in Louisa's opinion, with Uncle Sam and Aunt Lu, there was always enough to eat" (LaPlante 92).

6. In her journal of February 1883, she wrote: “Began a book called 'Genius.' Shall never finish it, I dare say, but must keep a vent for my fancies to escape it. This double life is trying, and my head will work as well as my hands" (Myerson and Shealy, 1989 238).

7. A similar inner struggle is detectable in Goethe's work. "In the ensemble that we have come to call 'Goethe,' the theoretician and the poet were often at war with one another. When he applied himself to the sciences, Goethe was often driven by a marked fascination for monstrosities, degeneracy (Abarten) and malformation. This can hardly be said to be the case in his poetical endeavors [...]. The trait of monstrosity might be lodged in the elegance of Faustian striving, in the demonic excess, that is, of a desire for knowledge" (Ronell 129-130).

8. Bronson Alcott's and Abigail May's commitment to social reform within Concord's transcendentalist circle is recorded in Martha Saxton's ground-breaking biography of Louisa May Alcott.

9. In her 1852 Journals, Louisa May Alcott wrote: "Our poor little home had much love and happiness in it, and was a shelter for lost girls, abused wives, friendless children, and weak and wicked men" (Myerson and Shealy, 1989 67).

10. "There was C,-alas, that I must write was! Beautiful, gifted, young and full of the lovely possibilities which give some girls such an indescribable charm" ("My Girls," in Alcott, 1878, reprinted in Aunt Jo's Scrap-Bag, 1889, vol. IV, p. 14).

11. "Placed where it would have been natural for her to have made herself a young queen of society, she preferred something infinitely better, and so quietly devoted herself to the chosen work that very few guessed she had any [...]. [T] he beautiful girl, sitting in her own pretty room, told me how, for a long time, she and others had stepped out of their safe, sunshiny homes to help and save the most forlorn of our sister women" ("My Girls" 14-15).

12. "Always simply dressed this young sister of charity went about her chosen task when others of her age and position were at play; happy in it, and consciously preaching a little sermon by her 
lovely life. Another girl, who spent her days reading novels and eating confectionery, said to me, in speaking of $\mathrm{C}-$

'Why doesn't she dress more? She is rich enough, and so handsome I should think she would.'

Taking up the reports of several charities which lay on my table, I pointed to C's name among the generous givers, saying,-

'Perhaps that is the reason,' and my visitor went away with a new idea of economy in her frivolous head, a sincere respect for the beautiful girl who wore the plain suit and loved her neighbor better than herself" ("My Girls" 16).

13. "Now, what would I like to see in New York? Stewart's big candid store, I suppose, ladies make their first pilgrimage there,' said a friend soon after my arrival in that queer mixture of London and Paris.

'I don't care a pin for any big store! I want to see the Newsboys' Lodging House and School' was my answer, for I felt as if that building was more beautiful than the white marble square of the millionaire, splendid as it is" ("An Evening Call” 257).

14. Thus Whitney A. Womack describes the "upper- and middle-class women who paid periodical visits to the poor, to slums, factories, or red-light districts to provide spiritual and material redemption" (Womack 113).

15. As Monika Elbert puts it, "The family is deemed respectable because it is following its Christian path of helping others, even though they themselves have nothing" (20). In this regard, she quotes Louisa's 1852 Journal: "Father and Mother had no money to give, but gave them sympathy, help, and if blessings would make them rich, they would be millionaires. This is practical Christianity" (Myerson and Shealy, 1989 67).

16. "Refuge? Is there a refuge for destitute children in New York? Then Babylon is not as bad as I thought it. What is this refuge?'

'It is a prison where juvenile delinquents are trained to habits of-'

'A prison! send her to a prison? Never!' burst forth old Hurricane, rising and marching up to the recorder" (Southworth 48).

17. Writing to her father on November 26, 1875, Louisa explains: "Mr. Powell has been twice to see me, and we go to visit the charities of New York next week. I like to see both sides, and generally find the busy people more interesting" (Myerson and Shealy, 1995 201).

18. "'You see I used to go round fiddling with my father, and another man, till he died. [...] [I]t was horrid; so cold in winter, and hot in summer. And I got tired; and they were cross sometimes; and I didn't have enough to eat.'

Nat paused to take a generous bite of gingerbread, as if to assure himself that the hard times were over, and then he added regretfully, - 'But I did love my fiddle, and I miss it: Nicolo took it away when father died, and wouldn't have me any longer, 'cause I was sick.'

'You'll belong to the band if you play good. See if you don't'" (Little Men 398-399).

19. Abigail May's children were actively involved in the almsgiving (the so-called "friendly visits") which she paid to her poorest neighbors, including the German immigrants' home whose fatal inspection cost the life of her third daughter. In her typical autobiographical style, Louisa reported the episode of Beth's scarlet fever in chapters XVII-XVIII of Little Women.

20. Rousseau's primitivism, his Romantic association of childhood with innocence, and their influence on British poets and on Bronson Alcott's pedagogy are debated in: Vogel; Agamben; Elbert; Elbert and Ginsberg.

21. "A prize is sometimes offered to the lad who saves up the most in the month. As we were told this, standing by the wide, low table full of slits, each numbered and leading to a small safety vault below, a boy came in and dropped a handful of pennies down the hole belonging to him" (“An Evening Call” 261).

22. Sánchez-Eppler provides material evidence by reporting exerpts from the 1855 Annual Report of the Children's Aid Society: “The Newsboys' Lodging Houses shared this ethos, often providing the 
boys with better clothes, and by their second year of operation they opened [...] a table in which each boy should have his own money-box numbered, where his earnings could be deposited. [...] This has given the first taste of the pleasure of saving" (14, quoted in Sánchez-Eppler $168 \mathrm{fn} .34$ ).

23. "[S] unshine will be on it as it makes its summer cruises, manned by waifs and strays whom its good commander has rescued from the great sea of poverty and sin, where so many little boats go down for want of a pilot to bring them safely into port" ("A Visit to the School Ship," Merry's Museum, March 1869, reprinted in The Youth's Companion, May 24, 1888, and in The Sketches of Louisa May Alcott 230).

24. This removal plan features prominently in the letters to Louisa's nephews Frederick and John Pratt of December 4, 1875, which clearly provided the basis for her Newsboys' Lodging House's tale: "The savings-bank was a great table all full of slits, each one leading to a little place below and numbered outside, so each boy knew his own. Once a month the bank is opened, and the lads take out what they like, or have it invested in a big bank for them to have when they find homes out West, as many do, and make good farmers. One boy was putting in some pennies as we looked, and I asked how much he had saved this month. 'Fourteen dollars, ma'am,' says the thirteen-year-old, proudly slipping in the last cent. A prize of $\$ 3$ is offered to the lad who saves the most in a month. [...] He also told me how that very day a neat, smart young man came in, and said he was one of their boys who went West with a farmer only a little while ago, and now he owned eighty acres of land, had a good house, and was doing well, and had come to New York to find his sister, and to take her away to live with him. Wasn't that nice? Lots of boys do as well. Instead of loafing round the streets and getting into mischief, they are taught to be tidy, industrious, and honest, and then sent away into the wholesome country to support themselves.

It was funny to see 'em scrub in the bath-room, -feet and faces,-comb their hair, fold up their own clothes in the dear cubbies, which make them so happy because they feel that they own something" (Myerson and Shealy, 1995 203-204).

25. "Some of the well-to-do fellows decline the breakfast of tea and bread and syrup here provided and go away to feast sumptuously on coffee and cakes. These dissipated youths also clamor at times to have their bank opened before the month is out, even offer to pay for the favor, so that they may waste their substance in riotous living-go to the theater, have a supper, and then for a time sleep in the street and live as they can" ("An Evening Call" 260).

26. "The gymnasium must be a lively place when the lads are there; for even hard work does not exhaust all their energies, it seems, and they give vent to their buoyant spirits before bedtime by swarming up and down ladders, turning somersaults, and swinging so high that the ceilings would suffer if boards full of nail points were not put up to restrain their soaring ambition" ("An Evening Call" 260).

27. "I long to take these young creatures into some safe corner to grow up in the sunshine and pure air they needed" ("A New Way to Spend Christmas" 266).

28. Later included in the 1876 Silver Pitchers collection, the story initially appeared in 1875 as an advertising feature in The National Elgin Watch Company's Illustrated Almanac, illustrated and published in Chicago by Culver, Page, Hoyne.

29. "I was struck by the decent appearance and good behavior of the boys, for I had expected to see a somewhat disorderly set. They were certainly not well dressed nor polished in manners, but looked intelligent, were generally tidy, and minded their own affairs in a capable sort of way that both amused and pleased me" (“An Evening Call” 261).

30. "Upstairs we saw the dormitories, with the long rows of neat beds, in tiers of two; and the vision of one hundred and eighty boys snugly tucked up there was so delightful and amazing that I could not realize it as a sober fact. The other vision of a hundred and eighty boys all enjoying a general scrimmage was even more delightful, and that I could realize fully.

When I asked our conductor by what magic he got this brigade of boys into their beds and kept them there, he laughed and said: 'You see, ma'am, the poor chaps are so tired after being out at 
work all day that they are glad to keep still when night comes. Now and then new boys try to get up a breeze, but we have a watchman and he keeps things quiet"' (“An Evening Call" 259).

31. "Some were reading [...] lounging in easy attitudes on the benches, with newly washed bare feet and smooth heads, which seemed to be prepared for morning, to save time; for we were told that many were up and away by five o'clock to sell early papers on trains and boats [...] it was very comforting to see so many lads safe, and warm, and clean and happy in this home, instead of being left out in the streets to sin and suffer, uncared for just when most needing care" ("An Evening Call" 258).

32. "How I should like to be that watchman, for a time at least, and see these 'poor chaps' peacefully asleep under the blue coverlets-if any lay awake with a pain or trouble, to ease it if I could, and say the word, or give the soothing path that strengthens weak will and conquers temptation by the thought that 'somebody cares.' To tuck up the little ones and give a good night kiss, if they wanted it, trying to keep soft the hearts that often grow hard or hungry for the lack of love.

But I fancy there is a special angel sent to keep guard over these motherless boys, else how is it that they do so well, and often come back from Western homes to thank those who helped them, and to go and do likewise?" ("An Evening Call” 260).

33. The narrator notices "[o]ne little chap, only six, [...] locking up his small shoes and ragged racket as it they were great treasures. I asked about little Pete, and the man told us his brother, only nine, supported him and took care of him entirely, and wouldn't let Pete be sent away to any home, because he wished to have 'his family' with him" (Myerson and Shealy, 1995 202).

34. "If I had not thought it would look sentimental, I should have liked to take him up and have a good chat with him to find out how things seemed to such a lonely creature. I fancy his views of life would not have been very extensive, but eminently practical and cheerful, for Patsey evidently appreciated his present well-being and had no fears for the future, no doubts of brother Pete's entire ability to steer their boat into some safe harbor.

Bon voyage, brave little brother, and thank God that you have so soon found one of the blessed school ships, whence you can sail by and by for the long voyage, with the memory of past kindness warm at your hearts and the white flag of the Children's Aid Society flying from the masthead" ("An Evening Call” 259).

35. For example, among the newsboys: "One big fellow with a very dirty face glowered at us, as if he decidedly objected to us and considered our call impertinent. I inferred from his manner that 'shines' had not been plentiful that day, and nothing but the immediate offer of the boots of the company would brighten the cloud of gloom and blacking that obscured his countenance.

Another boy agreeably relieved the monotony of general virtue which prevailed by whisking a newspaper over his shoulders, like my cloak, and prancing behind our backs with such a comical imitation of the tall woman's walk that I was immensely tickled. [...] I trust they felt that a kindred soul lived under the big cloak, and if a droll fellow ever sees this article in any of his papers, he will own that the laugh is on my side now.

I enjoyed my call so much that I mean to go again some Sunday and see how my young men appear then. Or on Christmas, if possible, and make sure that little Patsey has one present, at least, whether he has a sock to hang up or not" ("An Evening Call” 261-262).

36. "It seems that his parents were dead, and this child and a nine-year-old brother were left alone in the world. One would have thought two such babies had no refuge but an orphan asylum, but brother Pete preferred to support the family himself and did so with the help of this newsboys' friend. Actually, little nine-year-old took care of his brother, buying and begging his clothes, paying for his bed and food, and getting on bravely with business meantime. I longed to see this small hero, but he had not yet come in, being one of the boys who sell late papers" ("An Evening Call" 258). 
37. "[T]hough he had seemed a lively mite when left to his own devices, he was as meek as a mouse when he stood before us, in a tidy blue shirt and trousers that had evidently been 'built' for a larger man. His little face was scrubbed till it shone, and his yellow hair stood straight up in an independent sort of way, while a pair of quick blue eyes peeped at us with the sidelong glance of one used to looking out for squalls and dodging blows" (“An Evening Call” 259).

\section{ABSTRACTS}

This article examines Louisa May Alcott's tales based on her mid-1870s tour of philanthropic institutions for New York's homeless boys. In an effort to make her lessons more palatable to her young readership and reflecting her own beliefs in the themes of self-improvement, Alcott often euphemizes the shelters' evidently oppressive and exploitative dimensions. Devoid of moralism, Alcott's tales also carry strong biographical accents, from her own experience of poverty to her own temperance journey and, most importantly, the humanistic spirit which she inherited from her parents' own charity efforts.

Cet article se penche sur les récits inspirés à Louisa May Alcott par ses visites des institutions caritatives pour garçons sans abris à New York au milieu des années 1870 . Soucieuse de divertir autant que d'instruire son jeune public et convaincue de la réussite par le travail, Alcott minimise la part d'exploitation et d'oppression pourtant manifeste dans les refuges pour garçons qu'elle décrit. Exempts de tout moralisme, ses récits présentent de forts échos biographiques avec la vie de l'autrice: son expérience de la pauvreté, son chemin vers l'abstinence et surtout un humanisme directement hérité de ses parents et de leurs actions caritatives.

\section{INDEX}

Keywords: Alcott (Louisa May), philanthropy, charity, boys' shelters, reform literature, children's literature

Mots-clés: Alcott (Louisa May), philanthropie, œuvres caritatives, refuges pour garçons, littérature réformatrice, littérature pour la jeunesse

\section{AUTHOR}

\section{DANIELA DANIELE}

Università degli Studi di Udine 